\title{
Effects of blended e-Learning: a case study in higher education tax learning setting
}

\author{
Li-Tze Lee ${ }^{1,2^{*}}$ and Jason C Hung ${ }^{1,2}$
}

\author{
* Correspondence: \\ leelitze@ocu.edu.tw \\ 'Department of Marketing and \\ Supply Chain Management, \\ Overseas Chinese University, 40721 \\ No. 100, Chiao Kwang Rd., Taichung \\ City, Taiwan, R.O.C \\ ${ }^{2}$ Department of Information \\ Technology, Overseas Chinese \\ University, 40721 No. 100, Chiao \\ Kwang Rd., Taichung City, Taiwan, \\ R.O.C
}

\begin{abstract}
This article has two main objectives. First, we describe the design of an e-learning system for a University Income Tax Law course. Second, we analyze and explore learning results in terms of students' learning satisfaction and learning achievement. Learning achievement was examined by questions derived from the course content while learning satisfaction was analyzed based on an adaptation of the Technology Acceptance Model (TAM).

Results indicate that neither gender nor the school system affect students' e-learning system satisfaction. Since students' knowledge and exposure to computers are equal regardless of gender or educational background this reduces the significance of both these variables. Participating samples are divided into three groups: traditional, fully on-line and blended learning. We find, however, a statistically significant difference existed in learning achievement among groups. The blended learning group, combining on- line learning with paper-and-pencil testing, has the best learning achievement among the three groups.

Keywords: E-learning; Income Tax Law; Learning Achievement; TAM model
\end{abstract}

\section{Introduction}

It is known that e-learning as a widely accepted tool in many fields such as higher education, business and training [1]. The development of the Internet facilitates e-learning in the form of applications and reduces the boundaries to learning and compliments traditional teaching methods. Tax education, as part of a discipline in a higher education, receives little research attention for many years. However, tax knowledge, changed from time to time, is a life skill required by adults around the world. For example, to report personal income tax and know how to deduct your personal exemptions. Many prior studies focus on teaching methodology (e.g., [2,3]) or report characteristics of tax courses (e.g., [4]). Few studies address innovative approaches to implementing e-learning course in tax education. Craner and Lymer [4] indicate that taxation courses rarely use internet as instructional delivery method. Hite and Hasseldine [3] reinforce this point by arguing that continuing education for students and instructors should focus on creating effective learning environment using the internet for taxation courses. Therefore, this study implemented an e-learning web system on Income Tax Law subject in order to provide variety of learning environment and learning motivation. In addition, an experiment was conducted to assess student learning achievement as well as learning satisfaction.

\section{Springer}

C 2015 Lee and Hung; licensee Springer. This is an Open Access article distributed under the terms of the Creative Commons Attribution License (http://creativecommons.org/licenses/by/4.0), which permits unrestricted use, distribution, and reproduction in any medium, provided the original work is properly credited. 


\section{Literature review}

In the following sections, we present a short background about e-learning. In addition, we describe how short history about Technology Acceptance Model and its applications in prior studies. Third, we detail literatures about student learning achievement in an e-learning environment.

\section{E-learning}

E-learning relates to distance education facilitated through the use of electronic media such as the Internet, DVDs, CD-ROMs, videotapes, television or cellphones. E-learning brings tangible advantages in terms of accessibility to a learning environment that can be used anywhere and at anytime [5]. This approach to education is often characterized as improving learning efficiency while achieving cost reductions [1].

E-learning delivers information to end users via the Internet and is superior to traditional approaches in its capability to update, store, retrieve and share learning information. E-learning consists of three fundamental elements: (a) use of the internet for updating, retrieving, dispatching and sharing messages, (b) the availability of a standardized technology based platform that facilitates learning at a distance and (c) general concept learning instead of problem solving [6].

Henderson [7] states that E-learning brings a variety of benefits that include: (a) reduced costs, for example in traveling expenses, (b) students learn in a place of their own convenience, (c) student's define the pace of their learning and (d) institutions increase flexibility in their educational systems.

Blended learning refers to the integration of traditional classroom teaching with e-learning activities in order to enrich delivery in the learning environment $[8,9]$. Blended learning involves putting the major learning activities online while retaining traditional classroom teaching in a way that captures the best of face-to-face classroom teaching and online learning [8].

Jacob [10] explores benefits and barriers in blended learning in two US high schools and found that both students and parents' accept this kind of learning due to its efficiency; administrators and teachers thus increased the allocation of resources to blended learning. Vaughan [11] examines perceptions on blended learning in higher education and found that blended learning facilitated flexibility in learning times and increased individuals' responsibility for learning.

\section{Technology acceptance model}

The Technology Acceptance Model (TAM) explains the factors that underlie users' engagement with and use of technology [12]. The TAM explains and predicts technology acceptance in terms of two factors i.e., perceived usefulness and perceived ease-of-use.

TAM model has been widely used in many fields. In 2000, Lederer, Maupin, Sena, and Zhuang [13] conduct an e-mail survey sent to 163 participants to express their opinions about ease of use and usefulness of websites. The study employs ease of understanding and finding to estimate ease of use of websites while information quality in terms of revisiting websites to estimate usefulness. The study confirmed that TAM is a good instrument providing inclusive investigation for web designer, researcher, and manager to predict web users' preferences 
In 2007, Kim and Chang [14] use TAM model to investigate users' perceptions about the design and operation of health information websites. Results from the structural equation method showed that characteristics were divided into three groups: factor impact perceived usefulness and perceived ease of use, factor impact only perceived ease of use, and not direct impact on either perceived usefulness and perceived ease of use. In health information websites, two key functional characteristics extended from original TAM are essential: 'usage support' and 'customization'

Recently, Polancic et al. [15] explore major factors which influence framework's popularity and success. Their research instrument revised from TAM and Seddon's information system. This study collected 389 questionnaires and analyzed data by using structural equation modeling. Their results maintained that two key factors, continues usage and perceived usefulness, have huge influence on success of frameworks and revise TAM provided a relationship between usage and successful of frameworks while usage brings financial benefits to the company.

Gender is an important issue when studying technology acceptance. Belenky et al. [16] state that learning methods are different by gender. Male learners tend to be independent learners or active learners while female learners tend to be group learners by building network connections when they study. To study the relationship between gender and technology acceptance, Ong and Lai [17] conducte a survey on 67 female and 89 male Science-based Industrial Park employees. They found that males are influenced by computer usefulness while females are influenced by computer self-efficacy and ease of use.

Smart and Cappel [18] conduct a study on student perceptions toward online learning in terms of leaner characteristic, course content, and learning context. They found that no significant differences in gender or business and non-business students but significant differences among fourth-year (senior) versus non-fourth-year (non-senior) students since fourth-year students have more computer experiences and positive technology attitudes toward learning than non-fourth-year students.

Lo and Hong [19] also examine learners' satisfaction toward e-learning experiences. Elements such as delivery method, content, system, and interaction were studied in terms of e-learning satisfaction while gender as a moderator factor. There are three hundred and twenty-two Malaysian public university students participated in this study. Research showed that delivery method, content, system, and interaction have significant impact on e-learning satisfaction and gender only impacts on interaction factor since male and female learn differently.

In 2012, González-Gómez, Guardiola, Rodríguez and Alonso [20] study gender issue in e-learning environment from survey on 1185 students from Universidad de Granada in Spain. Their results indicated that female learners have positive learning satisfaction than male learners and females concern about studying plan and use different learning channels to communicate with teachers.

\section{Learning achievement}

Learning achievement is an important factor when study e-learning. Al-Mutairi and Jordan [21] investigate student e-learning performance by involving 566 graduate students (353 female and 213 male) in the study. Factors such as gender, working 
student, status martial were investigated about student learning performance. Results revealed that female students' academic performance is better than their male counterparts and young students perform better than elder and non-national students. Lim and Morris [22] study learning outcome in the effects of learner and instruction characteristics under blended learning environment. However, they found that no gender effect on student learning outcome but age, prior e-learning experiences and study time are factors which can distinguish learning outcome.

In addition to gender issue, group learning difference has become an important issue on e-learning achievement. In 2004, Rovai and Jordan study sense of community on full time graduate students in higher education. Sixty eight students were divided into three groups: (a) traditional course with 26 enrolled (b) blended course with 28 enrolled, and (c) fully online course with 25 enrolled. Results found that blended learning course with attributes of learning-centered and active learning through cooperation and social construction produce a higher sense of community than either traditional or full online courses.

Additionally, Taradi et al. [23] investigate 121 second-year medical student learning outcome and satisfaction in acid-base physiology at the University of Zagreb Medical School. They found that in problem-based learning, blend web based group produces summative final grades than face-to-face group. El-Sofany et al. [24] propose a designed system with courses quizzes and for training and teaching. Sixty students have been randomly assigned to two groups: paper quiz and computer quiz groups. Results of their study found that computer group performs better and has positive attitudes toward computers used in their learning.

On the other hand, in 2010, Kanthawongs, Wongkaewpotong, and Daneshgar [25] compare learning outcomes among students in either non web-based or web-based enterprise resource planning (ERP) simulated classrooms. Experimental group involves students self-learned from prepared presentation slides in a web-based ERP simulated classroom while control group involves students study with peers and the teacher by using textbooks in a non web-based ERP simulated classroom. Results found that non web-based ERP simulated group produced higher achievement scores than web-based ERP simulated group.

\section{Website establishment and instructions}

Website design function and function instruction is presented in this chapter. The website homepage of this research is "http://ccw2.ocu.edu.tw/accounting/testt/". Membership is active once registration process is completed. This website can be divided into the user's interface and the administrator's interface; and, both interfaces can be differentiated as the following seven sections:

\section{Website establishment}

Software used in this research for designing the website is Dreamweaver CS4 because this software provides designers to create and manage website with its user-friendly interface (Figure 1). 


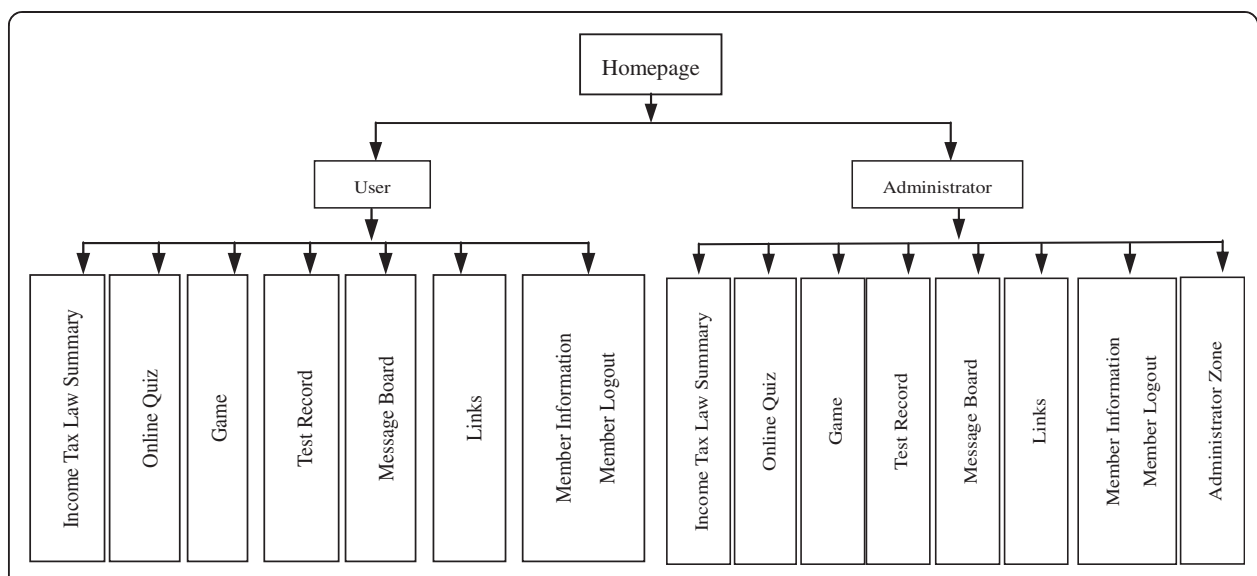

Figure 1 Website establishment map.

\section{Income tax law}

The course contents of Income Tax Law are separated into three chapters and transformed into website files. With one click, digital online learning is available right away (Figure 2).

\section{Online quiz}

Online learning quiz provides learners to access and test once they login to the system and without limitations of time or space. When learners complete online quizzes and click on "Done" button, the system will finish grading and provide the correct answer for each question automatically. If the answer is correct, the system will pop up a message of "You got it! 5 points". If the answer is incorrect, it will show "Wrong answer!" and provide the correct answer (Figure 3).

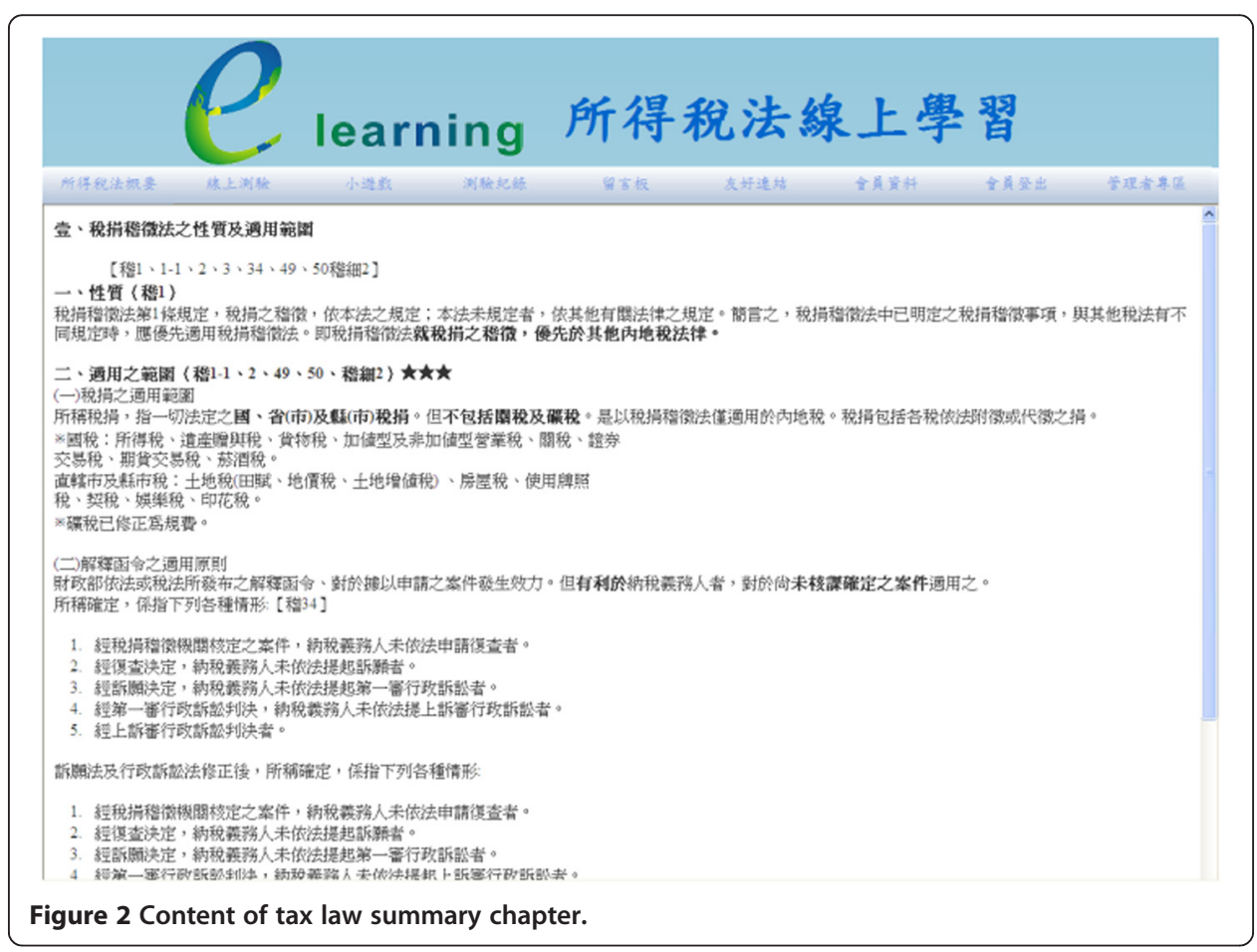




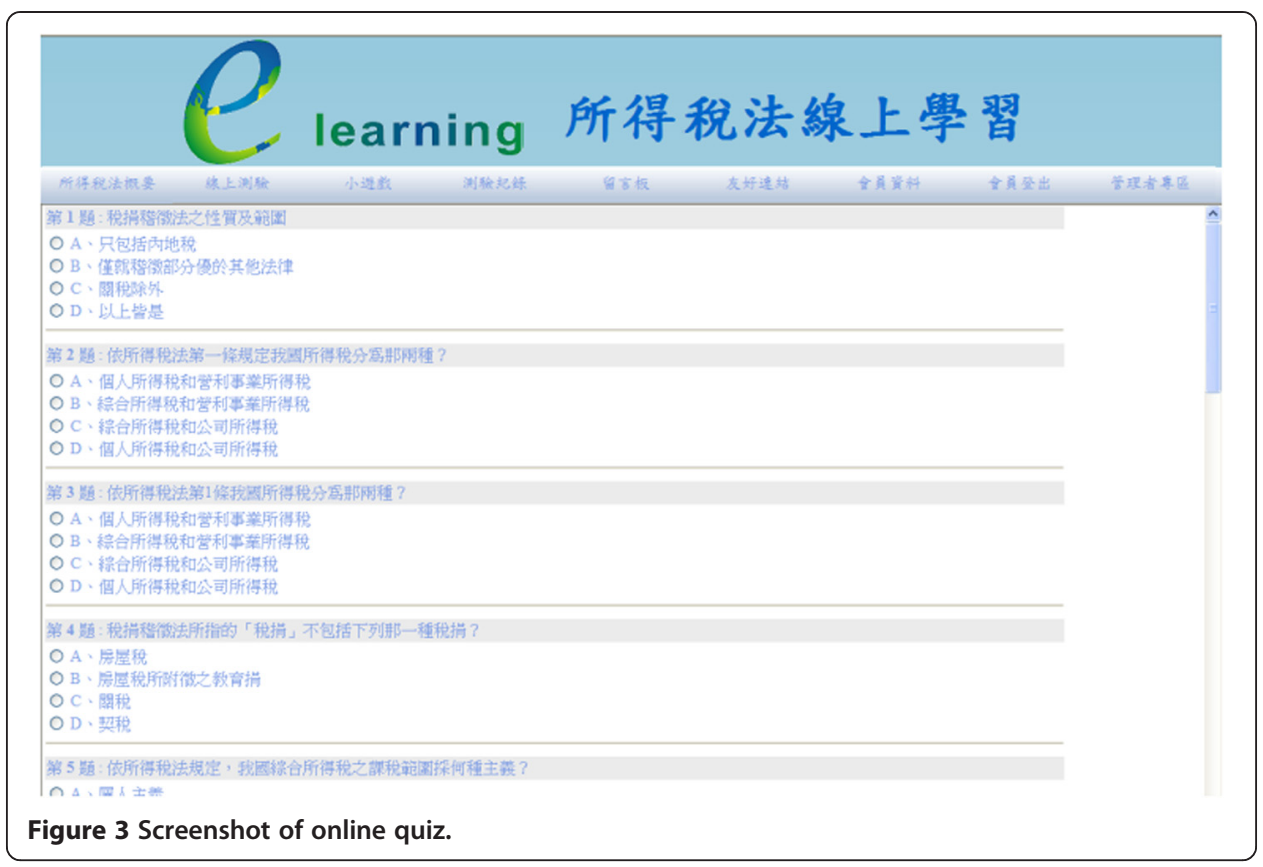

\section{Game}

The game, a coin catching activity, is designed to increase learning interest in this study. Three chapters can be selected according to learner's preference and multiple-choice questions are presented with four options: A, B, C, and D. The game will end when learners completed 20 questions. The final score will be showed on the game screen in the end of the game. Learners can check and review their learning progress after the game test (Figure 4).

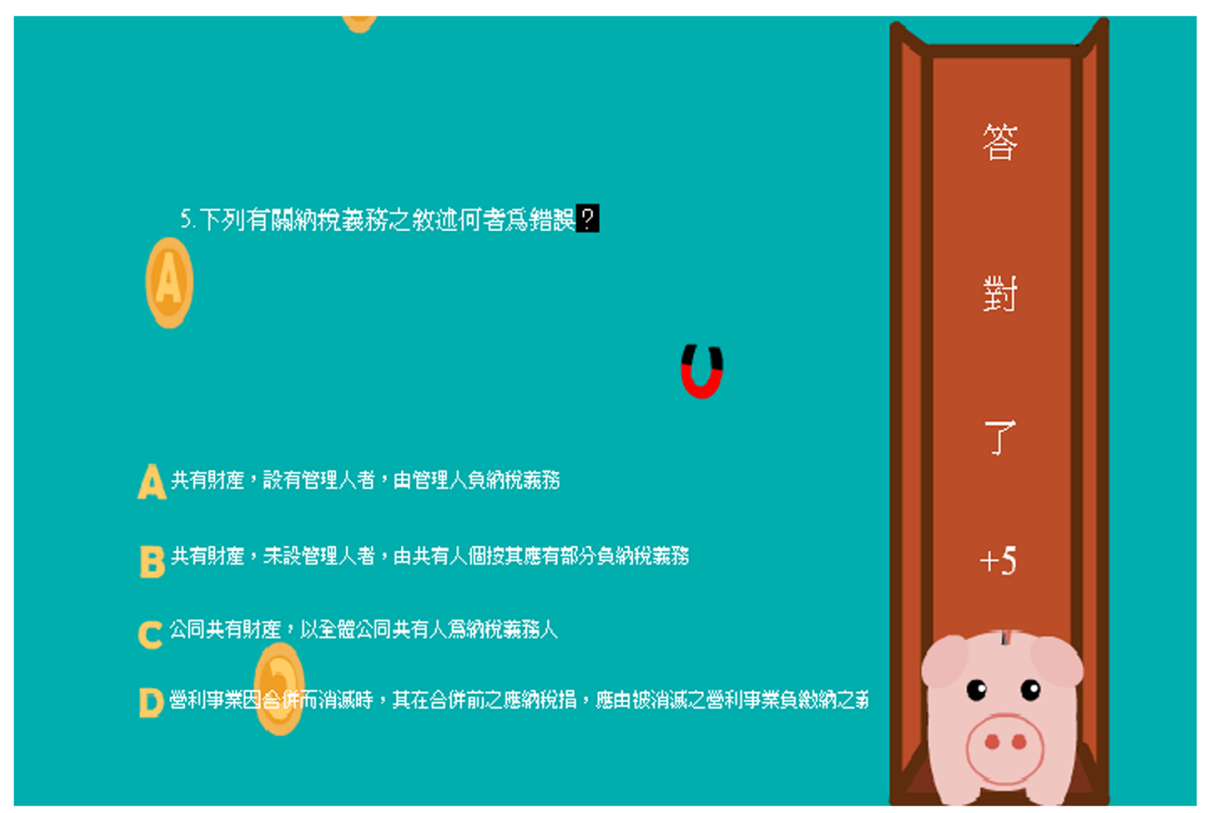

Figure 4 Screenshot of game. 


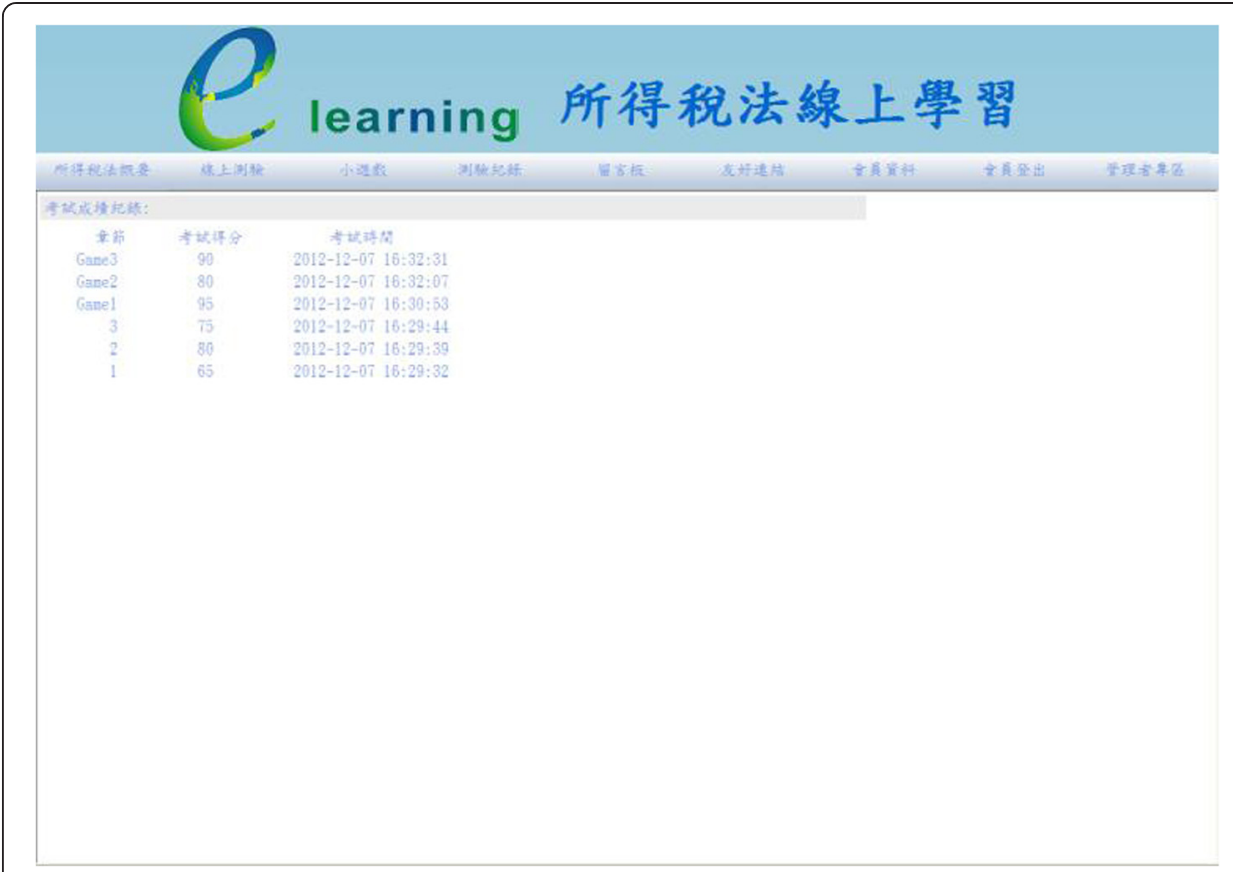

Figure 5 Test record.

\section{Test record}

When learners complete the courses and the online quizzes, they can click on "Test Record" to review their own study progress on the record page, where all the completed chapters, quiz scores and the time of quizzes are listed (Figure 5).

\section{Administrator zone}

The function of administrator zone is for examining the study progresses of learners and answering messages in a timely basis in order to achieve the goals of interactive tutorials and learning (Figures 6 and 7).

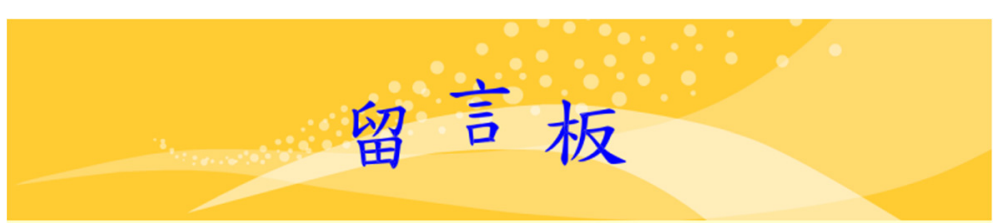

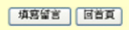

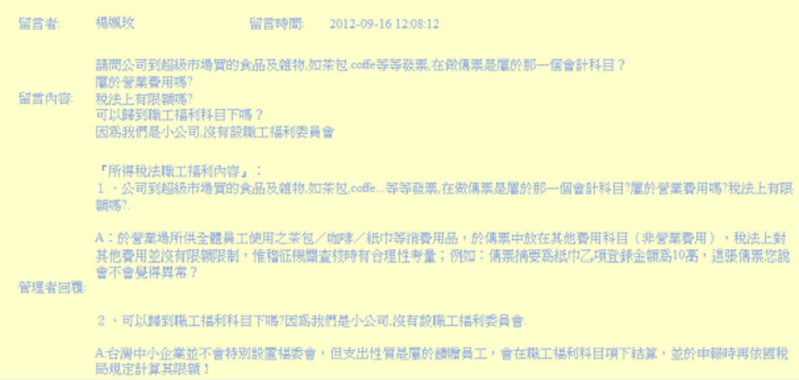

Figure 6 Score review page of administrator zone. 


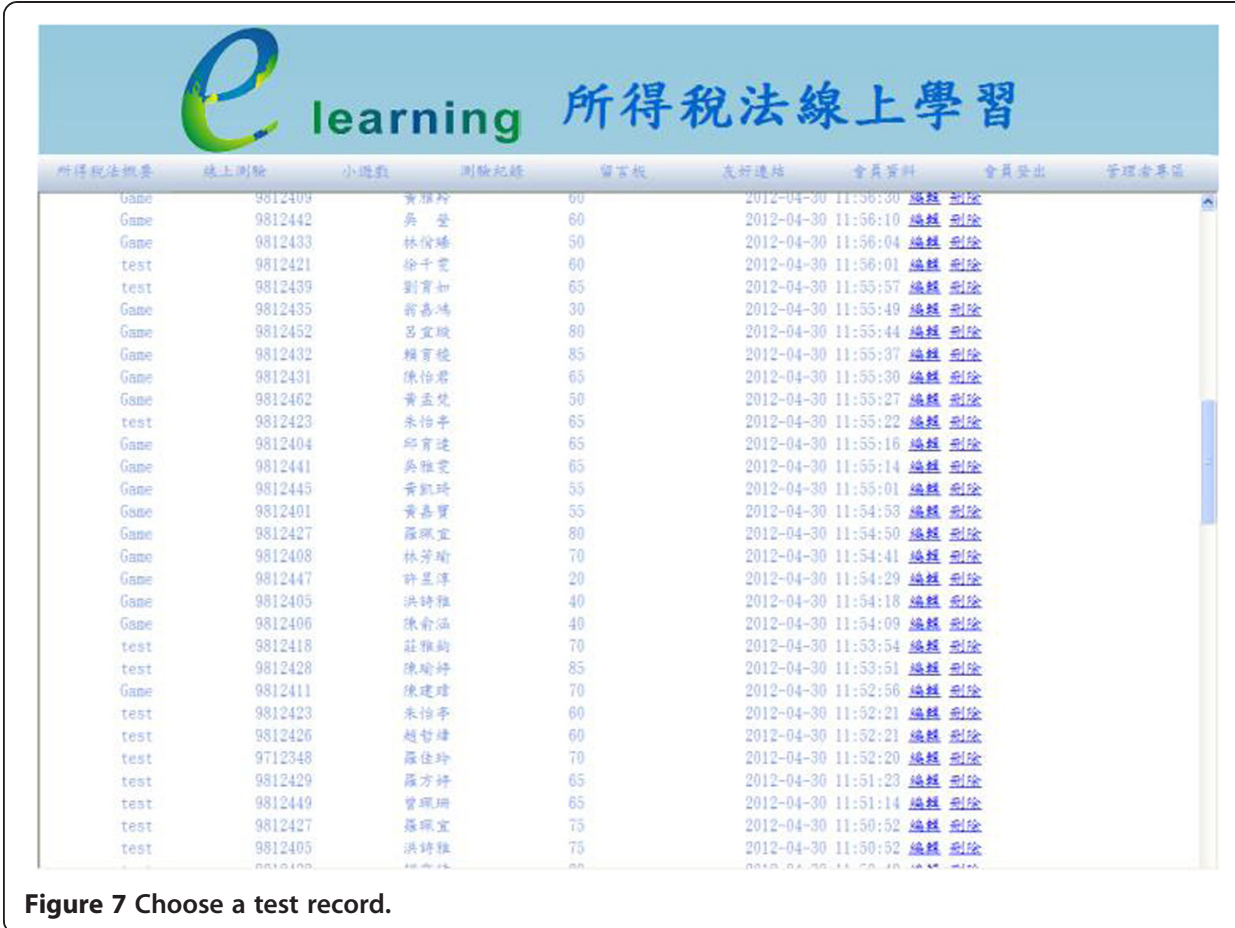

\section{Data analysis}

\section{Sampling}

There are 151 students majored in Accounting and Information participated in this study. The majority of sample subjects are females which consist $75.50 \%$ and males consist $24.50 \%$. Regarding student classification, $54.97 \%$ are university and $45.03 \%$ are junior college. Students are randomly assigned to three groups (traditional, blended, or fully on-line) as shown in Table 1.

\section{Research process}

There are two main research objectives in this study. First, we describe the design of an e-learning system for a University Income Tax Law course. Second, we analyze and explore learning results in terms of students' learning satisfaction and learning achievement. It took us 3 months to implement the design of this e-learning platform by testing, editing, and revision to finish the first phase of this study.

Table 1 Demographic of student information

\begin{tabular}{llll}
\hline & Variable & N & Percentage \\
\hline Gender & Male & 37 & $24.50 \%$ \\
Classification & Female & 114 & $75.50 \%$ \\
& University & 83 & $54.97 \%$ \\
Group & Junior College & 68 & $45.03 \%$ \\
& Traditional & 52 & $46.36 \%$ \\
& Blended & 46 & $23.18 \%$ \\
& Fullyon-line & 53 & $30.46 \%$ \\
\hline
\end{tabular}


The second phase of this study is the evaluation of this system. Students' learning achievement and satisfaction were analyzed by a content test and a questionnaire adaptation of the Technology Acceptance Model (TAM). All students were randomly assigned into three groups: traditional, blended, and fully on-line groups. Among these three groups, traditional group studied and took tests with paper materials, blended group studied with digital online system but took tests with paper materials, and fully on-line group studied and took tests one digital online basis. The research procedure included three steps and two hours for the implementation. First, students were randomly assigned into groups and seated. After explaining the research procedures, they started to learn online or study with paper materials according to their groups. Third, after the learning period, students took either online tests or paper tests to measure their learning achievement and answered TAM questionnaires to measure their learning satisfaction.

\section{Reliability and validity}

A reliability analysis can be allotted into two components: stability and consistency. However, results may contain some errors; that is, the smaller the error, the higher reliability; on the contrary, the greater the error, the lower the reliability. This study uses reliability coefficient to measure the degree of the reliability. The greater the reliability coefficient, the higher the measured reliability is. Cronbach's alpha is to examine the reliability, and if the value greater than 0.7 it is considered as a high reliability; if the value is smaller than 0.35 , the reliability is low [26]. In this study, TAM questionnaire reliability analysis was analyzed with 5 aspects. The result Cronbach's alpha value was 0.880; and, this indicates the reliability of this questionnaire is quite high.

Regarding validity, this questionnaire was created according to theory of related literatures and suggestions and modifications were obtained from discussions of three experts in this field. Therefore, this research should be provided with considerable face validity and adequate construct validity.

\section{Result on TAM questionnaire}

The factor of gender effect system usefulness, ease of use, attitude toward using, behavior intention, and the satisfaction of actual uses of the digital learning system was studied here. Through the independent sample T-test, the differences based on the gender were found in Question 1 and Question 3. The average score in Question 1 (3.9912) of female learners was higher than male learners' (3.7027). This shows that female learns believed that digital learning mode helps them to get familiar with the course content, compared to male learners. Also, the average score in Question 3 (3.8947) of female learns was higher than male learners' (3.6486). This indicates that female learners believed digital learning mode helps them to understand the course content, compared to male learners.

Secondly, this study discusses whether the system usefulness, ease of use, attitude toward using, behavior intention, and the satisfaction of actual use of digital learners to the digital learning system varied according to classification. Results from independent sample T-test show that Question 2, Question 4, Question 5, Question 6, Question 15, Question 18, Question 19, Question 23, and Question 24 differ according to classification. Interestingly, except for Question 19, junior college students have higher scores than university students. It may be that junior college students with younger age and having positive learning attitudes toward digital learning system than university students (Table 2). 
Table 2 Independent sample T-test based on gender and classification

\begin{tabular}{|c|c|c|c|c|}
\hline Factor & Question & Content & Gender & Classification \\
\hline & Q1 & $\begin{array}{l}\text { I believe that this digital learning system helps me } \\
\text { to be familiar with the course content }\end{array}$ & $(2.3888) *$ & $(0.8581)$ \\
\hline & Q2 & $\begin{array}{l}\text { I believe that this digital learning system can } \\
\text { improve my learning efficiency }\end{array}$ & $(1.0700)$ & $(1.6943) *$ \\
\hline \multirow[t]{5}{*}{ Usefulness } & Q3 & $\begin{array}{l}\text { I believe that this digital learning system provides } \\
\text { positive helps on the understanding of the course } \\
\text { content }\end{array}$ & $(1.9975) *$ & $(1.5642)$ \\
\hline & Q4 & $\begin{array}{l}\text { I believe that this digital learning system allows me } \\
\text { to understand the course content easily }\end{array}$ & $(1.9202)$ & $(1.4564) *$ \\
\hline & Q5 & $\begin{array}{l}\text { Overall, my evaluation to this digital learning system } \\
\text { is positive }\end{array}$ & $(1.2439)$ & $(1.4327) *$ \\
\hline & Q6 & $\begin{array}{l}\text { I think the operation of tax law digital study system } \\
\text { is simple for me }\end{array}$ & $(0.9671)$ & $(2.9734) *$ \\
\hline & Q7 & $\begin{array}{l}\text { I think browsing of tax law digital learning system is } \\
\text { simple for me }\end{array}$ & 0.5235 & $(1.2668)$ \\
\hline \multirow[t]{5}{*}{ Ease of use } & Q8 & $\begin{array}{l}\text { I think the user interface of tax law digital learning } \\
\text { system is simple for me }\end{array}$ & 0.6192 & $(2.3010)$ \\
\hline & Q9 & $\begin{array}{l}\text { I think tax law digital learning system is clear and } \\
\text { easy to read for me }\end{array}$ & 0.3980 & $(0.9599)$ \\
\hline & Q10 & Overall, I think using this system is easy & 0.6116 & $(1.6266)$ \\
\hline & Q11 & I think tax law digital learning system is convenient & $(0.0635)$ & $(2.8388)$ \\
\hline & Q12 & I think tax law digital learning system is interesting & $(1.3782)$ & $(1.0306)$ \\
\hline \multirow{5}{*}{$\begin{array}{l}\text { Attitude } \\
\text { toward } \\
\text { using }\end{array}$} & Q13 & I think tax law digital learning system is helpful & $(1.0559)$ & $(0.1813)$ \\
\hline & Q14 & I would like to use this system for studying tax law & $(0.3038)$ & $(1.3859)$ \\
\hline & Q15 & Overall, my evaluation for this system is positive & $(0.8562)$ & $(1.9706)^{*}$ \\
\hline & Q16 & $\begin{array}{l}\text { I am willing to participate if there is a digital } \\
\text { learning program }\end{array}$ & $(1.1352)$ & $(2.5256)$ \\
\hline & Q17 & $\begin{array}{l}\text { I am willing to participate if there is a program } \\
\text { designed with this model in the future }\end{array}$ & $(0.6680)$ & $(2.2812)$ \\
\hline \multirow{6}{*}{$\begin{array}{l}\text { Behavioral } \\
\text { intention to } \\
\text { use }\end{array}$} & Q18 & $\begin{array}{l}\text { I will choose to study tax law with digital learning } \\
\text { system if it is allowed in the future }\end{array}$ & $(0.5865)$ & $(0.7577) *$ \\
\hline & Q19 & $\begin{array}{l}\text { I will keep studying tax law with digital learning } \\
\text { system if it is allowed in the future }\end{array}$ & $(0.8879)$ & $0.1337 *$ \\
\hline & Q20 & $\begin{array}{l}\text { Overall, I have a very high intention of using tax law } \\
\text { digital learning system }\end{array}$ & $(1.2976)$ & $(1.6338)$ \\
\hline & Q21 & $\begin{array}{l}\text { I will actually use digital study system if digital } \\
\text { learning activity starts now }\end{array}$ & $(1.4397)$ & 0.1928 \\
\hline & Q22 & $\begin{array}{l}\text { I would like to participate some similar digital } \\
\text { learning programs again }\end{array}$ & $(0.2361)$ & $(2.2162)$ \\
\hline & Q23 & $\begin{array}{l}\text { I believe that participating digital learning activities } \\
\text { will improve the learning efficiency }\end{array}$ & $(2.2211)$ & $(0.9289) *$ \\
\hline \multirow[t]{3}{*}{ Actual use } & Q24 & $\begin{array}{l}\text { I like to participate digital learning activities because } \\
\text { it can assist on traditional learning }\end{array}$ & $(0.5103)$ & $(0.7297) *$ \\
\hline & Q25 & $\begin{array}{l}\text { I like to participate digital learning activities because } \\
\text { it can replace traditional learning completely }\end{array}$ & $(1.6214)$ & 0.6560 \\
\hline & Q26 & $\begin{array}{l}\text { Overall, my evaluation of this system from my } \\
\text { actual use experience is positive }\end{array}$ & $(0.2670)$ & (1.3200) \\
\hline
\end{tabular}

Note: Significance is marked by stars: ${ }^{*} p<0.05$ (2-tailed). 
Table 3 Analysis of variance result on question 11

\begin{tabular}{lllllll}
\hline & Variance & SS & df & MS & F & Sig. \\
\hline Q11 & Between & 5.7317 & 2 & 2.8658 & 4.8635 & $0.0090^{*}$ \\
& Within & 87.2087 & 148 & 0.5892 & & \\
& Total & 92.9404 & 150 & & & \\
\hline
\end{tabular}

Note: Significance is marked by stars: ${ }^{*} p<0.05$ (2-tailed).

At last, this study investigated whether group impacts the system usefulness, ease of use, attitude toward using, behavior intention, and the satisfaction of actual use of digital learners to the digital learning system. Through single factor analysis of variance, Question 11, Question 15, Question 19 and Question 22 were found differ among groups. Question 11 states that "I think tax law digital learning system is convenient". Statistic significant differences were found that students in the traditional group believe that digital learning system is convenience than fully online students and students in the blend group believe that digital learning system is convenience than fully online students. Question 15 states that "Overall, my evaluation for this system is positive". Statistic significant differences were found that students in the traditional group have positive attitudes to digital learning system than fully online students. Question 19 states that "I will keep studying tax law with digital learning system if it is allowed in the future" were different according to their groups.

Statistic significant differences were found that students in the traditional group believe that they will use this system in the future than fully online students and the same in the blend group than fully online students. Question 22 states that "I would like to participate some similar digital learning programs again”. A statistic significant difference was found that students in the blend group agree that they like to participate digital learning system than fully online students. Related results are stated in the following Tables 3, 4, 5 and 6.

\section{Result on tax learning achievement}

In addition to learning satisfaction, this study also examined learning achievement on this digital online learning system based on genders, classification, and groups. First, results on independent sample T-test indicated that no significant differences were found between genders (Sig. $=0.7098>0.05$ ) or classifications (Sig. $=0.2292>0.05$ ); and, the related information are as shown in Table 7.

Next, the descriptive statistics of learning achievement based on group indicated that students in the blended group have the highest scores (74.6739), followed by the fully online group (67.7358), and the lowest is the traditional group (67.3077). The related data are as shown in Table 8.

Through one-way analysis of variance of learning achievement, a significant difference was found among groups (Sig. $=0.0255^{*}<0.05$ ); and, the related information are as shown in Table 9.

Table 4 Analysis of variance result on question 15

\begin{tabular}{lllllll}
\hline & Variance & SS & df & MS & F & Sig. \\
\hline Q15 & Between & 3.4448 & 2 & 1.7224 & 3.4659 & $0.0338^{*}$ \\
& Within & 73.5486 & 148 & 0.4970 & & \\
& Total & 76.9934 & 150 & & & \\
\hline
\end{tabular}

Note: Significance is marked by stars: ${ }^{*} p<0.05$ (2-tailed). 
Table 5 Analysis of variance result on question 19

\begin{tabular}{lllllll}
\hline & Variance & SS & df & MS & F & Sig. \\
\hline Q19 & Between & 4.2053 & 2 & 2.1026 & 3.1907 & $0.0440^{*}$ \\
& Within & 97.5298 & 148 & 0.6590 & & \\
Total & 101.7351 & 150 & & & \\
\hline
\end{tabular}

Note: Significance is marked by stars: ${ }^{*} p<0.05$ (2-tailed).

Table 6 Analysis of variance result on question 22

\begin{tabular}{lllllll}
\hline & Variance & SS & df & MS & F & Sig. \\
\hline Q22 & Between & 4.5597 & 2 & 2.2799 & 3.9732 & $0.0209^{*}$ \\
& Within & 84.9237 & 148 & 0.5738 & & \\
& Total & 89.4834 & 150 & & & \\
\hline
\end{tabular}

Note: Significance is marked by stars: ${ }^{*} p<0.05$ (2-tailed).

Table $7 \mathrm{~T}$ test on tax learning achievement base on Gender and classification

\begin{tabular}{lllllll}
\hline & Variable & N & M & DS & T value & Sig. \\
\hline Tax Learning Scores & Male & 37 & 66.4865 & 14.6185 & $(1.5034)$ & 0.7098 \\
& Female & 114 & 70.7456 & 15.0843 & & \\
& University & 83 & 66.1446 & 13.3737 & $(3.3174)$ & 0.2292 \\
& Junior College & 68 & 74.0441 & 15.8881 & & \\
\hline
\end{tabular}

Table 8 Statistic description on tax scores by group

\begin{tabular}{lllllll}
\hline & Group & N & M & SD & Min & Max \\
\hline Tax Learning Scores & Traditional & 52 & 67.3077 & 14.5677 & 35 & 100 \\
& Blended & 46 & 74.6739 & 16.8458 & 35 & 100 \\
& Fully on-line & 53 & 67.7358 & 12.9186 & 35 & 100 \\
\hline
\end{tabular}

Table 9 One-way analysis of variance on tax learning achievement

\begin{tabular}{llllll}
\hline Variance & SS & df & MS & F & Sig. \\
\hline Between & $1,640.1019$ & 2 & 820.0509 & 3.7608 & $0.0255^{*}$ \\
Within & $32,271.4875$ & 148 & 218.0506 & & \\
Total & $33,911.5894$ & 150 & & & \\
\hline
\end{tabular}

Note: Significance is marked by stars: ${ }^{*} p<0.05$ (2-tailed).

Table 10 LSD post Hoc comparison

\begin{tabular}{lllll}
\hline & Group Comparison & MD & SE & Sig \\
\hline Tax Learning Scores & Blended & 7.3662 & 2.9889 & $0.0149^{*}$ \\
& $\begin{array}{l}\text { Traditional } \\
\text { Blended } \\
\text { Fully on-line }\end{array}$ & 6.9381 & 2.9756 & $0.0211^{*}$ \\
\hline
\end{tabular}

LSD post-hoc tests compare differences between groups. ${ }^{*} p<0.05$ (2-tailed). 
Compared with students in the traditional group, students in the blended group have better learning efficiency on tax law; and, the statistical significant difference was found (Sig. $=0.0149^{*}<0.05$ ). In addition, compared with students in the fully online group, students in the blended group have better learning achievement on tax law; and, the statistical significant difference was found $\left(\right.$ Sig. $\left.=0.0211^{*}<0.05\right)$. However, no significant difference was found between traditional and fully on-line groups; and, the related information are as shown in Table 10.

\section{Conclusion and discussion}

\section{Conclusion}

The research is to set up income tax law digital online learning system and discuss the learning satisfaction and learning efficiency. Learning satisfaction is analyzed through TAM questionnaire and learning efficiency is examined through contest test results. Study results showed that learning satisfaction on online digital learning does not affect by gender, classification, or group. In other words, learners regardless of gender (male or female), classification (junior college or university) or group (traditional, fully online, or blended) have similar learning satisfaction. It can imply that computer learning experiences and online training opportunity are similar in this study. Our result is similar to prior studies. For examples, Smart and Cappel's [18] found that gender o does not impact their learning satisfaction and Lo and Hong [19] also found that gender does not have a significant impact on e-learning satisfaction. Even no difference was found in online tax learning satisfaction between genders, females performed better than their male counterparts in tax learning achievement in this study. This result is consistent to Al-Mutairi's and Jordan [21] study that female students have better academic performance than male students.

In terms of student classification, the result is quite different from prior studies. Smart and Cappel [18] found older students with more computer experience and possess more positive attitudes with online learning. While Paechter et al. [27] study indicated that no difference was found among ages on online learning course achievement. Interestingly, in this study, students in junior college group have higher tax learning achievement than university group. Reasons may be that young students have more experiences exposing themselves to online learning and they are more concerned about their scores since it will affect their future schools option.

One of the important finding of this study is that students in blended learning group have the highest tax learning achievement scores than both fully-online and traditional groups. However, no difference was fond between fully-online and traditional groups. Corresponding to our findings, Rovai and Jordan [28] and Taradi, et. al's [23] identified that blended course students obtain better grades than traditional or fully online course.

\section{Discussion}

Income Tax law is a practical and important course to both college students and adults. The digital online learning system helps to provide a diverse learning environment. Even there is no difference on learning satisfaction in terms of gender, classification or group, a significant learning difference is found among groups. Blended learning group with online learning and paper test outperformed the other two groups which provide a perspective for teaching and learning practice. 
Subjects and the scope of the research are suggested for future study. Student samples from both technical colleges and academic universities can be included as subjects to make the research more thorough. In addition, different disciplines are suggested to explore whether different subject areas can be one of factor to affect online learning satisfaction and efficiency. A longitudinal study with experimental period and learners background is suggest increasing research reliability and validity.

\section{Competing interests}

The authors declare that they have no competing interests.

\section{Authors' contributions}

The concept and the manuscript were made by LL, who carried out all the research design and performed the statistical analysis. $\mathrm{JH}$ participated in the website design and testing as well as literature revision. All authors read and approved the final manuscript.

Received: 5 September 2014 Accepted: 2 February 2015

Published online: 30 April 2015

\section{References}

1. Nicholson P (2007) A history of e-learning. In: Fernández-Manjón B et al (eds) Computers and Education: e-learning, from theory to practice. Springer, Springer Netherlands, pp 1-11

2. Hite P (1996) An experimental study of the effectiveness of group exams in an individual income tax class. Issues in Accounting Education 11(1):61-75

3. Hite P, Hasseldine J (2001) A primer on tax education in the United States of America. Accounting Education 10(1):3-13, doi: 10.1080/0963928011003473 4

4. Craner J, Lymer A (1999) Tax education in the UK: a survey of tax courses in undergraduate accounting degrees. Accounting Education 8(2):127-156, doi: 10.1080/096392899330973

5. Engelbrecht E (2005) Adapting to changing expectations: Post-graduate students' experience of an e-learning tax program. Computers \& Education 45(2):217-229, doi:10.1016/j.compedu.2004.08.001

6. Rosenberg M (2001) E-Learning: Strategies for Delivering Knowledge in the Digital Age. McGraw Hill Companies, Columbus, $\mathrm{OH}$

7. Henderson AJ (2003) The E-Learning Question and Answer Book: A Survival Guide for Trainers and Business Managers. AMACOM, New York, NY

8. Garnham C, Kaleta R (2002) Introduction to hybrid courses. Teaching with Technology Today 8(6):5

9. $\quad$ Singh H (2003) Building effective blended learning programs. Education Technology 43(6):51-54

10. Jacob AM (2011) Benefits and barriers to the hybridization of schools. Journal of Education Policy, Planning and Administration 1(1):61-82

11. Vaughan N (2007) Perspectives on blended learning in higher education. International Journal on E-Learning 6 (1):81-94

12. Davis FD (1989) Perceived usefulness, perceived ease of use, and user acceptance of information technologies. MIS Quarterly 13(3):319-340

13. Lederer AL, Maupin DJ, Sena MP, Zhuang Y (2000) The technology acceptance model the World Wide Web. Decision Support Systems 29(3):269-282

14. Kim D, Chang H (2007) Key functional characteristics in designing and operating health information websites for user satisfaction: An application of the extended technology acceptance model. International Journal of Medical Informatics 76:790-800, doi:10.1016/j.ijmedinf.2006.09.001

15. Polancic G, Hericko M, Rozman I (2010) An empirical examination of application frameworks success based on technology acceptance model. The Journal of Systems and Software 83:574-584, doi:10.1016/j.jss.2009.10.036

16. Belenky MF, Clinchy BM, Goldberger NR, Tarule JM (1997) Women's ways of knowing: The development of self, voice, and mind. Basic Books, New York, NY

17. Ong C, Lai H (2006) Gender differences in perceptions and relationships among dominants of e-learning acceptance. Computers in Human Behavior 22:816-829, doi:10.1016/j.chb.2004.03.006

18. Smart K, Cappel J (2006) Students Perceptions of Online Learning: A Comparative Study. Journal of Information Technology Education 5:201-219

19. Lo M, Hong TC (2011) Modeling user satisfaction in e-learning: A supplementary tool to enhance learning. Review of Business Research 11(2):128-133

20. González-Gómez F, Guardiola J, Rodríguez OM, Alonso MAM (2012) Gender differences in e-learning satisfaction. Computers \& Education 58(2):283-290, doi:10.1016/j.compedu.2011.08.017

21. AL-Mutairi A, Jordan HM (2011) Factors affecting business students' performance in Arab Open University: The case of Kuwait. International Journal of Business and Management 6(5):146-156, doi:10.5539/ijbm.v6n5p146

22. Lim DH, Morris ML (2009) Learner and instructional factors influencing learning outcomes within a blended learning environment. Educational Technology \& Society 12(4):282-293

23. Taradi SK, Taradi M, Radic K, Pokrajac N (2005) Blending problem-based learning with web technology positively impacts student learning outcomes in acid-base physiology. Advances in Physiology Education 29(1):35-39, doi:10.1152/advan.00026.2004

24. El-Sofany HF, Hasnah AM, ALJa'am JM, Ghaleb FFM, El-Seoud SA (2006) A web-based e-learning system experiment. International Journal of Computing \& Information Sciences 4(1):22-29 
25. Kanthawongs $P$, Wongkaewpotong $\mathrm{O}$, Daneshgar $\mathrm{F}$ (2010) A comparative study of students' learning outcome in non web-based and web-based ERP-simulated classroom environments. International Journal of Business Research 10(3):130-136

26. Guielford JP (1965) Fundamental statistics in psychology and education, 4th edn. Mcgraw Hill Inc, New York

27. Paechter M, Maier B, Macher D (2010) Students' expectations of, and experiences in e-learning: Their relation to learning achievements and course satisfaction. Computers \& Education 54(1):222-229, doi:10.1016/j. compedu.2009.08.005

28. Rovai AP, Jordan HM (2004) Blended learning and sense of community: A comparative analysis with traditional and fully online graduate courses. International Review of Research in Open and Distance Learning 5(2):1-13

Submit your manuscript to a SpringerOpen ${ }^{\mathcal{O}}$ journal and benefit from:

- Convenient online submission

- Rigorous peer review

- Immediate publication on acceptance

- Open access: articles freely available online

- High visibility within the field

- Retaining the copyright to your article

Submit your next manuscript at $\boldsymbol{\sim}$ springeropen.com 